\title{
Membership Committee Meeting Summary
}

\section{Sunday, January 22, 8:30-10am}

Attendees: Stephen Woods, Jessica Torrance, Bill Teichert, Rachel Dobkin; Julia Frankosky Attending Virtually.

The Membership Committee discussed how GODORT can be more effective in outreach, recruitment and publicizing our events, resources and mission. Including:

- MidWinter Promotions and Materials: The Gov Doc Recipe cookies were a hit, and we looked forward to the Happy Hour.
- Whether the role of the committee is to serve our members-foster community and develop leadership within the organization-or is it to connect with other librarians, library groups and allies.

- Whether the present and proposed GODORT organizational structure is suited to current and emerging trends in Gov Docs and Gov Info Librarianship. Establishing an organization-wide outreach \& marketing strategy (rather than leave each committee to work alone) might be more effective. Midwinter Networking: Other sessions attended. Potential civic engagement partnerships with EveryLibrary, Libraries Foster Community Engagement MIG and Washington Office. Would the Trump Administration offer new advocacy opportunities and responsibilities? 